(2) norden 



\section{Parhaat käytettävissä olevat menetelmät (BAT) \\ kalanviljelyyn Pohjoismaissa}

Jostein Solbakken, Lars Windmar, Helge Liltved, Jo Inge Hesjevik, Ragnar Johannson

TemaNord 2008:547 ] 


\section{Parhaat käytettävissä olevat menetelmät (BAT) kalanviljelyyn Pohjoismaissa}

TemaNord 2008:547

(C) Pohjoismaiden ministerineuvosto, Kööpenhamina 2008

ISBN 978-92-893-1699-6

Ekspressen Tryk \& KopicenterKansi:

OPainettu ympäristöä säästävälle paperille, joka täyttää pohjoismaisen Joutsenmerkin kriteerit.

Julkaisua voi tilata osoitteesta www.norden.org/order. Muita julkaisuja on osoitteessa

www.norden.org/publikationer

Printed in Denmark

Nordisk Ministerråd

Store Strandstræde 18

DK-1255 København K

Puh. (+45) 33960200

Faksi (+45) 33960202

\section{Nordisk Råd}

Store Strandstræde 18

DK-1255 København K

Puh. (+45) 33960400

Faksi (+45) 33111870

www.norden.org

\section{Pohjoismainen yhteistyö}

Pohjoismainen yhteistyö on yksi maailman laajimpia alueellisia yhteistyömuotoja. Yhteistyön perustana on maantieteellinen, historiallinen ja kulttuurinen yhteenkuuluvuus, ja sen piiriin kuuluvat Islanti, Norja, Ruotsi, Suomi ja Tanska sekä itsehallintoalueet Ahvenanmaa, Färsaaret ja Grönlanti.

Pohjoismaista yhteistyötä tehdään politiikan, talouden ja kulttuurin aloilla tärkeänä osana eurooppalaista ja kansainvälistä yhteistyötä. Pohjoismaisen yhteisön tavoitteena on vahva Pohjola vahvassa Euroopassa.

Pohjoismainen yhteistyö pyrkii vahvistamaan pohjoismaisia ja alueellisia etuja ja arvoja globaalissa maailmassa. Maiden yhteiset arvot lujittavat osaltaan Pohjolan asemaa yhtenä maailman innovatiivisimmista ja kilpailukykyisimmistä alueista. 


\section{Sisällisluettelo}

Johdanto .......................................................................................................... 5

Maalla olevien kalanviljely-laitosten ympäristövaikutukset....................................... 6

Menetelmät, joiden voidaankatsoa olevan BAT maallasijaitsevissa laitoksissa. ............... 7

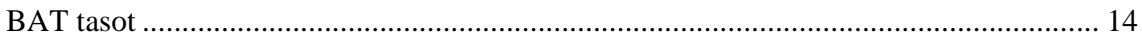

Merellä sijaitsevien laitostenympäristövaikutukset ................................................ 15

Menetelmät, joiden voidaan katsoaolevan BAT merellä tapahtuvassakalankasvatuksessa.17

\section{Johdanto}

Kalanviljely Pohjoismaissa tuottaa kalaa pääasiassakulutukseen, mutta myös istutuksiin järviin javesialueille, joiden kalakannat ovat uhattuina taipienenemässä. Kaloja viljellään yhteensä noin 12eri merikala- ja makeanveden lajia. Näiden lajientuotanto edustaa huomattavaa osaa Euroopankalanviljelyn vuosittaisesta tuotantomäärästä.Kalanviljelyn ympäristövaikutuksille on ominaistakorkea energiankulutus lämmitykseen, runsasvedenkulutus sekä orgaanisen materiaalin jaravintoaineiden fosforin ja typen päästöt.

Tämän tekstin tavoitteena on suositella parhaitakäytettävissä olevia menetelmiä (BAT), jotkavähentävät veden ja energian kulutusta, ravinnostaja ulosteista syntyvää kuormitusta sekä lääkkeidenja kemikaalien käyttöä kalanviljelylaitoksissamerellä ja maalla.

Tässä BAT määritellään nykyaikaisessakalanviljelyssä kokeilluiksi menetelmiksi, jotkavähentävät päästöjä sekä resurssien käyttöä jasamanaikaisesti ottavat huomioon kalan terveydenja hyvinvoinnin. Samalla edellytetään, ettämenetelmiä on mahdollista käyttää ottaenhuomioon tuotannolliset ja taloudelliset olosuhteet.

Perusmateriaali kerättiin valituilta maalla jameressä sijaitsevilta kalanviljelylaitoksilta. Tietojasaatiin myös ympäristöviranomaisilta ja kulloinkinkyseessä olevan menetelmän laitteiden toimittajilta.

Esiteltävien menetelmien yhteydessä viitataanreferenssilaitokseen tai menetelmä on yleinenkäytäntö kalanviljelyssä. Investointikustannuksetvaihtelevat paljon Pohjoismaiden välillä, jaannettuja arvoja on siksi vain pidettävä ohjeellisina.

Teksti on lyhennelmä raportista Parhaat käytettävissä olevat menetelmät (BAT)kalanviljelyyn Pohjoismaissa, Kööpenhamina,Pohjoismaiden Ministerineuvosto, TeemaPohjoinen 2005.
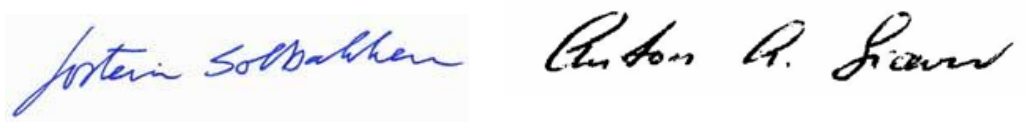


\section{Maalla olevien kalanviljely-laitosten ympäristövaikutukset}

Pohjoismaissa maalla olevien kalanviljelylaitostenkoko vaihtelee villejä kantoja vahvistaviinistutuksiin poikasia tuottavista maalammikoistasuuriin ruokakalaa tuottaviin laitoksiin. Lajit, joitaviljellään, ovat lohi, kirjolohi, nieriä, meritaimen,järvitaimen, siika, ankerias, kuha, turska,ruijanpallas, piikkikampela, kirjomerikissa jameribassi.

Istukaslaitos, jonka jätevedet johdettiin makeaanveteen, tuotti 79 milj. poikasta/istukasta, kun taassisävesistöön jätevetensä johtava ruokakalalaitostuotti 38.500 tonnia, joka jakautui 7 erilajiin(vuonna 2000/2001).

Meriveteen päästönsä johtavista laitoksistapoikaslaitokset tuottivat 183 milj.poikasta/istukasta, kun taas maalla olevatruokakalalaitokset tuottivat 3.094 tonnia, jokajakautui 5 kalalajiin (vuonna 2000/2001).

Makeaan veteen päästönsä johtavat laitokset ovatmaalla sijaitsevia hautomo- ja poikaslaitoksia,kassikasvatuslaitoksia makeissa vesissä,kalankasvatuslammikoita ja maalla oleviajatkokasvatuslaitoksia. Kalankasvatuslammikotvastaavat suurimmasta tuotantomäärästä.Meriveteen päästönsä johtavat maalla sijaitsevatlaitokset käsittävät pääasiassa lohen ja kirjolohenhautomoita ja istukaslaitoksia

Maalla sijaitseva laitos, jossa on hautomo jajatkokasvatuslaitos, sisältää seuraavat vaiheet:emokalojen säilytys, mädin lypsy emokaloista/luonnollinen mädin kuteminen altaassa, munienhaudonta, starttiruokinta, poikasruokinta jajatkokasvatus. Prosessit käsittävät seuraavat;kalojen ruokinta, lajittelu ja kuljetus, rokotus,lääkitys, käsittely loisia vastaan, altaiden ja putkienpesu, kalojen keräily ja teurastus.

Ympäristövaikutukset on pääasiassa kuvattu maallasijaitsevan lohen ja kirjolohen istukaslaitoksessatapahtuvien prosessien avulla, koska nämä laitoksetedustavat suurta osaa maalla sijaitsevista laitoksistaPohjoismaissa.

\section{Energiankulutus}

Maalla sijaitsevat kalanviljelylaitokset käyttävätenergiaa veden lämmitykseen ja pumppaukseen,valaistukseen, hapen tuotantoon ja hapetukseensekä sisääntulevan veden UV -käsittelyyn.

Monilla laitoksilla on lämpöpumput, missätuloveteen luovutetun energian ja kompressoriinsekä pumppuihin johdetun energian välinen suhde (järjestelmän tehokerroin) on 10 ja 20 välillä. Kokonaisenergiankulutus maalla sijaitsevissakalanviljelylaitoksissa vaihtelee paljon eriPohjoismaiden sisällä ja välillä. Yleisesti tasovaihtelee välillä 0 ja $60 \mathrm{kWh} / \mathrm{kg}$ tuotettua kalaariippuen kalalajista, elinkierron vaiheesta,lämmitetäänkö vesi ja missä määrin se kierrätetäänuudelleen. 


\section{Vedenkulutus}

Vesi tuo kalalle happea ja kuljettaa pois kuona-aineita. Makea vesi otetaan pääasiassa läheisestävesistöstä, jolla on riittävän suuri valuma-alue.

Vedenkulutus vaihtelee myös paljon laitoksissa eriPohjoismaiden sisällä ja välillä. Arvot vaihtelevat6 - $160 \mathrm{~m} 3$ vettä/kg tuotettua kalaa. Suhteellinenvedenkulutus maassa, jossa makeaa vettä on vähänja/tai makeavesikustannukset ovat korkeat, onalhaisempi suhteessa maahan, jossa makeavesivaratovat runsaat.

\section{Lääkkeiden ja kemikaalien käyttö.}

Lääkkeiden ja kemikaalien käyttö maallatapahtuvassa kalanviljelyssä käsittää antibiootit,anestesia-aineet, fungisidit, kauppanimelläanthelmintika tunnetut ja muut loisten torjunta-aineet kuten formaliinin.

Antibioottien kulutus vaihtelee 21-760 kg/vuodessaPohjoismaiden välillä. Yksi myötävaikuttava syytähän voi olla kalojen käsittely sellaistenbakteeritautien, kuten Flavobacteriumpsychrophilum jaIchthyophtihirius multifilispuhjetessa taimenen viljelylaitoksilla, joita vastaanei ole olemassa rokotetta.

\section{Ruoan ja ulosteiden päästöt}

Maalla sijaitsevien hautomoiden jaruokakalalaitosten jätevesi koostuu rehuntähteistä,ulosteista, puhdistusaineista ja desinfiointiaineista. Rehuntähteet ja ulosteet sedimentoituvatresipienttiin. Suurin osa fosforista kulkeutuuympäristöön hukkaan menneen rehun ja ulosteidenmuodossa, kun taas typpi kulkeutuu ympäristöönliuenneessa muodossa, josta vain pieni osa onsitoutuneena partikkeleihin. Rehun kauttakulkeutuvan typen ja fosforin kokonaismäärästänoin $52 \%$ typestä ja 63 \% fosforista päätyyympäristöön, jos otetaan lähtökohdaksi rehukerroin1.04.

Ravintoaineiden päästöt vaihtelevat välillä 15 - 70kg typpeä ja 1-10 kg fosforia/tonnia tuotettua kalaa.Vaihtelua aiheuttaa veden kierrätyksen aste jarehunjätteiden ja ulosteidensuodatus/talteenottolaitteistot laitoksen omissapuhdistusyksiköissä.

\section{Menetelmät, joiden voidaankatsoa olevan BAT maallasijaitsevissa laitoksissa.}

Tämän kappaleen tiedot on kerätty seuraavantyyppisistä maalla sijaitsevistakalanviljelylaitoksista:

1. Kirjolohen ruokakalalaitos, jossa vedenkierrätyksen aste on korkea

2. Lohen ja kirjolohen istukaslaitos, jossaveden kierrätyksen aste onkeskinkertainen. 
3. Piikkikampelan ruokakalalaitos, jossaveden kierrätyksen aste on korkea.

4. Lohen ja kirjolohen istukaslaitos, jossaveden kierrätyksen aste onkeskinkertainen.

5. Kirjolohen ruokakalalaitos, jossa onsedimentaatiolaitos.

6. Kirjolohen ruokakalalaitos, jossa onosittainen veden kierrätys

7. Lohen ja kirjolohen istukaslaitos, jossamatala veden kierrätyksen aste.

\section{Vedenkulutuksen ja energiankulutuksenvähentäminen}

Se, kuinka paljon vedenkulutusta voidaan vähentää,riippuu lajista ja kehitysvaiheesta. Pienen kalanspesifinen hapenkulutus on korkeampi, ja sensietokyky aineenvaihdunnassa syntyville kuona-aineille on vähäisempi. Vedenkulutuksen vähentäminen pienentää jäteveden määrää , mikäyksinkertaistaa jäteveden puhdistamista.Sähkönkulutus lisääntyy laitoksen sisäisenpumppauksen yhteydessä ja hapenliukenemisasteen mukaan.

Vedenkulutusta maalla sijaitsevissapoikaslaitoksissa ja ruokakalalaitoksissa voidaanvähentää ottamalla käyttöön seuraavia menetelmiä:

- Lohikalojen poikaslaitoksessa voivathapetuslaitteet ja allaskohtaiset hiilidioksidinilmastimet mahdollistaa makean vedenkulutuksen vähentämisen 100:sta 53 m3:iin/kgtuotettuja smoltteja (Menetelmä nro 1,Taulukko 1, Kuva 1).

- Partikkelisuodattimen, biosuodattimen jahapettimen sisältävän kierrätysmenetelmänasentaminen voi vähentää makean vedenkulutusta vielä jopa 6,3 m3:iin/kg tuotettujasmoltteja (Menetelmä nro 2, Taulukko 1).

- Alhaisin veden- ja sähkönkulutus 10 - 500 glohikalojen tuotannossa saavutetaan asentamallakierrätysmenetelmä, jossa käytetäänmikrosuodatusta, biosuodatinta ja ilmaa vedenkuljetukseen ja ilmastukseen. Saavutettavamakean veden kulutus vähenee silloin 100:sta0,06 m3:iin/kg tuotettua kalaa, ja sähkönkulutuson 1,5 kWh/kg tuotettua kalaa (Menetelmä nro5, Taulukko 1).

- Maalla sijaitsevissa lämpimän vedenmerikalalajien jatkokasvatuslaitoksissa voidaanvedenkulutusta vähentää 100:sta 0,8 m3:iin/kgtuotettua kalaa kierrättämällä vettäpartikkelisuodatuksen, biosuodattimen,denitrifikaatiosuodattimen, fosforinlaskeutusjärjestelmän läpi ja lisäämällä veteenhappea ennen kuin se virtaa kala-altaisiin(Menetelmä nro 6, Taulukko 1, Kuva 2).Sähkönkulutus on silloin noin 11 kWh/kgtuotettua kalaa. 


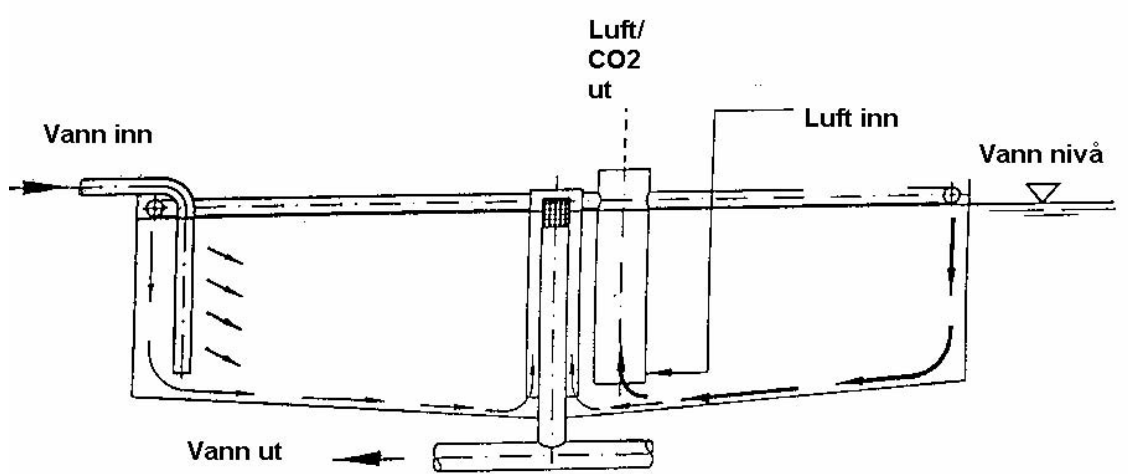

Kuva 1. Piirros menetelmästä, jossa vedenkulutusta on vähennetty hapettamalla ja ilmastamalla hiilidioksidia.

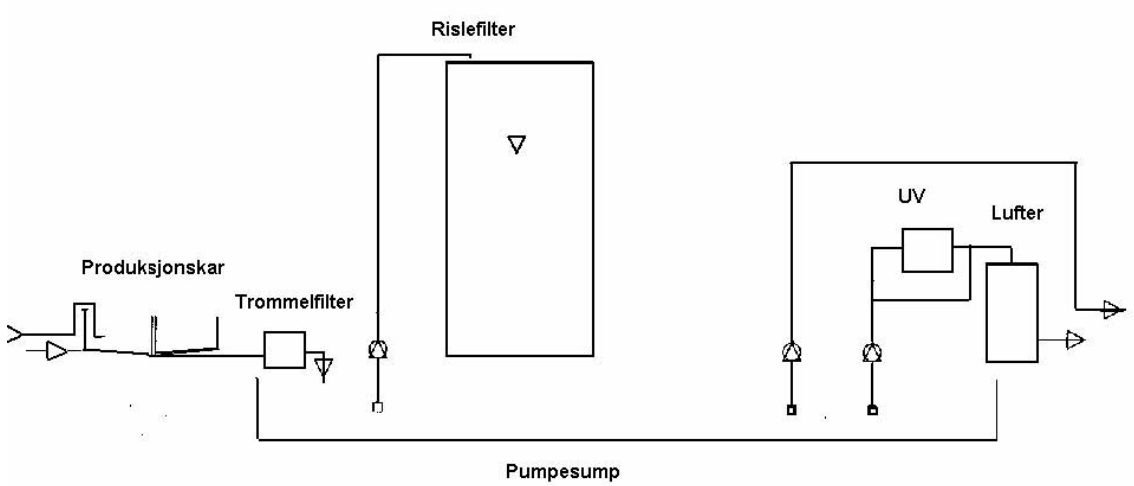

Kuva 2. Piirros menetelmästä, jossa veden uudelleen kierrätyksen aste on korkea lämpimän veden merikalalajienjatkokasvatuslaitoksessa.

Veden pumppaus

Kalanviljelyssä, missä täytyy pumpata suhteellisensuuria määriä vettä pienien korkeuserojen yli,suositellaan seuraavaa:

- Keskipakopumppujen ja siipipyöräpumppujenkäyttöä.

- Käyttää pumppuja niiden ominaisuuksienkeskitasolla.

\section{Orgaanisen materiaalin päästöjenvähentäminen}

Toimenpiteitä rehun kulutuksen vähentämiseksi

Rehun kulutuksen väheneminen vaikuttaa suoraanravintoaineiden päästöihin. Maalla sijaitsevissakalanviljelylaitoksissa rehun kulutusta voidaanvähentää:

- Käyttämällä sellaisia ruokintalaitteita, joihin onyhdistetty lohen tai muiden kalalajien uusimmatkasvumallit.

- Kytkemällä ruokintalaitteisiin lämpömittaritveden lämpötilan jatkuvaksi seuraamiseksi jasäännöstelemällä ruokintaa automaattisestiennaltamäärätyn mallin mukaan. Tällä 
tavallajärjestelmä itse säätelee rehun saantia altaassavallitsevien olosuhteiden mukaan.

- Käyttämällä suppiloa, joka asennetaan altaanviemäriin rekisteröimään syömättä jäänyttärehua. Syömätön rehu rekisteröidään niin, ettäinfrapunainen valonsäde taittuu, kunrehupelletit laskeutuvat suppilon läpi.

- Käyttämällä ruokintalaitteistoon kytkettyäruokintapäiväkirjaa, joka mahdollistaa jatkuvanoppimisen kerättyä tietoa analysoimalla ja tuoesille tietoa siitä, milloin kala syö, kuinkapaljon kala syö ja kuinka nopeasti kala syö.

Rehuntähteiden ja ulosteiden keräily

Seuraavia menetelmiä voidaan käyttäävähentämään rehun ja ulosteiden päästöjä.:

- Pyörrepuhdistajien ja hiukkasten kerääjienkäyttö jokaisen altaan viemärissä, ja kiinnisaatujen partikkeleiden kerääminen (Kuva 3, Menetelmä nro 2, Taulukko 1).

- Sedimentaatioaltaan asentaminen ennenviemäriä (Menetelmä nro 4, Taulukko 1).

- Rumpusiivilän käyttö viemärin yhteydessä(lohen istukaslaitos) vähentää rehuntähteistä jaulosteista suspendoituneiden aineiden päästöjäjopa $67 \%$ normaalissa rutiinitoiminnassa jajopa $94 \%$ tyhjennyksen tai altaiden”huuhtelun” yhteydessä.

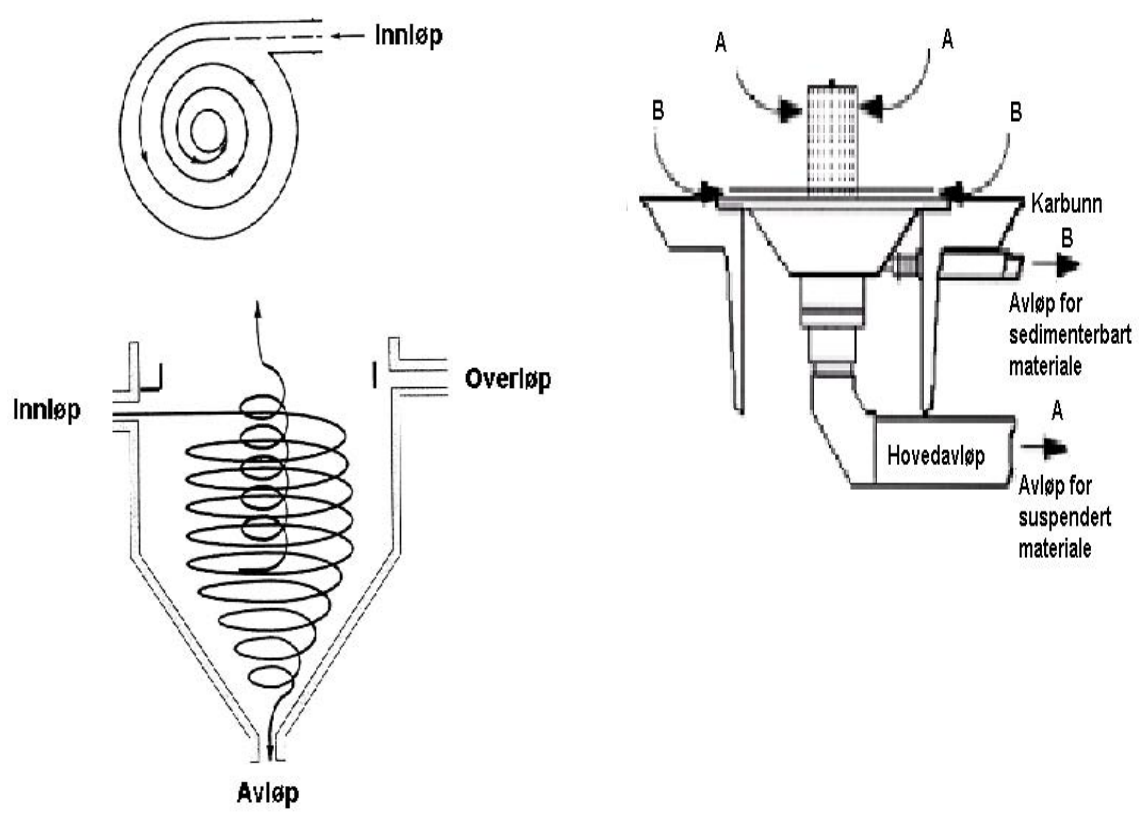

Kuva 3. Pyörreselkeytin (vas.) ja hiukkasten kerääjä (oik.), toimivat niin, että keskipakoisvoima ja painovoima johtavat hiukkaset erottelijankeskelle, missä konsentroitu vesi(rejektivesi) johdetaan viemäriin, kun taas kirkas faasi (selkeytetty vesi) poistetaan ylijuoksuputken kautta.. 
Pohjoismaisessa hautomossa ja 0,5 kg kirjolohenjatkokasvatuslaitoksessa on saavutettu varsin mataliapartikkelimaisen aineen ja ravintoaineiden päästöarvojakäyttämällä:

Kierrätysmenetelmää, joka sisältää hiukkastensuodatuksen tiheällä suodattimella, biosuodattimen,selkeyttävät ilmastusaltaat sekä paineilmaa vedenilmastukseen ja kuljetukseen. (Menetelmä nro 5,Taulukko 1).

Liuenneiden tai heikosti sitoutuneiden ravintoaineidenpäästöjen vähentäminen

Jätevedessä olevia liuenneita tai heikosti sitoutuneitatyppi- ja fosforimolekyylejä ei voida poistaamekaanisella suodatuksella tai sedimentoimalla. Kunveden uudelleenkäyttöprosentti on korkea, nitraatti voiakkumuloitua suljetussa laitoksessa, missä vesikierrätetään. Denitrifikaatiosuodattimen käyttö muuttaanitraatin typpikaasuksi, joka vapautuu ilmakehään.Ravintoaineiden päästöjä vähennetään edelleen:

- Asentamalla denitrifikaatiosuodatin suljettuunlaitokseen puhdistamaan vesi liuenneista taiheikosti sitoutuneista typpimolekyyleistä(Menetelmä nro 3,Taulukko 1).

- Asentamalla fosforinlaskeutusyksikkö suljettuunlaitokseen puhdistamaan vesi liuenneista taiheikosti sitoutuneista fosforimolekyyleistä. Arvojasaavutettavista tasoista ei ole saatavana (Menetelmänro 6, Taulukko 1),

- poistamalla flokkuloituneita partikkeleitafosforinlaskeutusyksiköstähihnasuodattimella (Menetelmä nro 6, Taulukko 1).

Lietteen käsittely

Lietteen kerääminen johtaa runsaaseen hiukkaspitoisenja heikosti sitoutuneen typen ja fosforin keräytymiseen.Lietteen käsittelyä voidään käyttää laitoksilla, missäjäteveden määrä on pieni suhteessa jäteaineidenkonsentraatioon. Mutta;

- kerätty liete on käsiteltävä prosesseissa, kutenpuristaminen (veden poisto) ja stabilointi ennenkuin sitä voidaan käyttää maanparannusaineena. 


\section{Menetelmiä kalan terveydentilanvarmistamiseksi}

Tässä kappaleessa kerrotaan vain tärkeimmistämenetelmistä. Nämä ovat tuloveden käsittely,hygieniasuunnitelmat/toimenpiteet, rokotus jakalatiheyden säätely.

Tuloveden laatu pohjoismaisissa maalla sijaitsevissalaitoksissa vaihtelee varsin paljon, mistä johtuen eianneta mitään tarkkoja lukuarvoja.

Seuraavia tekniikoita ja menetelmiä suositellaan maallasijaitsevien laitosten kalojen terveydentilanvarmistamiseksi.:

- UV säteilyannosten käyttö inaktivoi 99,9 \% kaloillepatogeenisista bakteereista tulovedessä.

- Riittävien otsonin jäännöskonsentraatioiden käyttöinaktivoi 99,9 \% tuloveden (makean veden)viruksista.

- Tuloveden partikkeleiden poistaminen mekaanisellasuodatuksella tuloveden UV ja otsonidesinfioinninvaikutuksen tehostamiseksi ja kalanpoikastenkidusärsytyksen vähentämiseksi.

- Hygieniasuunnitelmien tekeminen laitokseentulevan tartunnan, ja laitoksessa kalakantojen välillätapahtuvan tartunnan todennäköisyydenpienentämiseksi. Tämä käsittää suunnitelmatkalojen siirtämisestä ja työntekijöidenliikkumisesta, hygieniasulkujen rakentamisestaosastojen välillä, desinfektiorutiinit, rutiinittuntematonta alkuperää olevan biologisenmateriaalin tuomisesta laitokseen ja kalojenviemisestä pois laitoksesta.

- Kaiken myytävän kalan yksilöllinen rokottaminenasianmukaisilla rokotteilla ja asiaankuuluvillarokotusstrategioilla. Viljeltävän lohen ja kirjolohenrokottaminen useimmin esiintyviäbakteerisairauksia vastaan on johtanut antibioottienkulutuksen pienenemiseen jopa $99 \%$. Kustannuksetnousevat noin 11 \%kokonaistuotantokustannuksista smolttia kohti.

- Kalojen pitäminen ohjeellisten maksimitiheyksienrajoissa $(\mathrm{kg} / \mathrm{m} 3)$.

- Biomassan säätäminen tasolle, jolla kalojenhapentarve tyydytetään suurimmaksi osaksi vedenläpivirtauksen avulla mieluummin kuinhapettamalla. 
Menetelmiä myrkyllisten ja mahdollisestihaitallisten kemikaalien päästöjenvähentämiseksi

Myrkyllisten ja mahdollisesti haitallisten kemikaalien,erityisesti puhdistusaineiden, päästöjen vähentämiseksi,voidaan suorittaa seuraavia toimenpiteitä:

- Kaikkien pintojen pitäminen vapaanakalapatogeeneista bakteereista ja viruksista.

- Pesuaineiden käyttäminen rasvapitoisten kerrostenpoistamiseksi ja desinfektioaineiden vaikutuksenmaksimoimiseksi.

- Liukkaiden pintojen käyttäminen altaissa, seinissäja lattiassa.

- Keinovalon käyttäminen leväkasvustojenvähentämiseksi seinillä ja altaiden pohjassa.

- ”Höyrystin” -toiminnon sisältävänkorkeapainehuuhtelun käyttäminen korkeammanlämpötilan saavuttamiseksi, jolloin on helpompipoistaa rasvapitoisia aineita altaiden seiniltä.

\section{Kuolleiden kalojen käsittely}

Tavallinen menetelmä kuolleen kalan säilömiseksi onhapposäilöntä tankkiin laitoksella.

Menetelmän käyttöedellyttää infrastruktuuria ja vastaanottojärjestelmäähapposäilötylle kuolleelle kalalle.Menetelmä vähentää ympäristölle vähemmänystävällisten keinojen tarvetta ja varmistaa kuolleenkalan hygieenisen säilytyksen.

\section{Menetelmiä kalojen karkaamisen jakarkaamisen haitallisten vaikutustenvähentämiseksi}

Karkaaminen maalla sijaitsevilta laitoksilta onrajoitettua, mutta seuraavia toimenpiteitä voidaansuorittaa maalla sijaitsevilta laitoksilta tapahtuvankarkaamisen todennäköisyyden pienentämiseksi.

- Varmistustoimenpiteet siirrettäessä istukkaitamaalla sijaitsevista altaista kuljetusveneeseen,kuten esim. putkien ja haavien varmistaminen.

- Kiinteiden pohjasihtien asentaminen ja esteidenasentaminen viemärin suulle mahdollisestikaranneiden kalojen keräämiseksi. 


\section{BAT tasot}

Yhteenveto tasoista käytettäessä maalla sijaitsevillekalanviljelylaitoksille tarkoitettuja tekniikoita jamenetelmiä, jotka on kuvattu tässä raportissa onTaulukossa 1.Esitetyt tasot vaihtelevat sijainnistariippuvien spesifisten olosuhteiden mukaan ja niidenon siksi katsottava olevan vain ohjeellisia.Investointikustannukset vaihtelevat myös paljon

Pohjoismaiden välillä ja jälleen täytyy annettuja arvojavain pitää ohjeellisina.

\begin{tabular}{|c|c|c|c|c|c|c|c|}
\hline \multirow[t]{2}{*}{$\mathrm{Nr}$} & \multirow[t]{2}{*}{ Teknik } & \multirow[t]{2}{*}{ Referensanläggning } & \multicolumn{2}{|c|}{$\begin{array}{l}\text { Specifik belast- } \\
\text { ning }\end{array}$} & \multirow{2}{*}{$\begin{array}{l}\begin{array}{l}\text { Vatten- } \\
\text { förbrukning }\end{array} \\
\begin{array}{l}\text { l/kg produ- } \\
\text { cerad fisk }\end{array}\end{array}$} & \multirow{2}{*}{$\begin{array}{l}\begin{array}{l}\text { Energi- } \\
\text { förbrukn. }\end{array} \\
\mathrm{KWh} / \mathrm{kg} \\
\text { produ- } \\
\text { cerad fisk }\end{array}$} & \multirow{2}{*}{$\begin{array}{l}\text { Referens } \\
\text { anläggn. }\end{array}$} \\
\hline & & & $\begin{array}{l}\text { Kväve } \\
\text { Kg/ton } \\
\text { produ- } \\
\text { cerad } \\
\text { fisk }\end{array}$ & $\begin{array}{l}\text { Fosfor } \\
\text { Kg/ton } \\
\text { produ- } \\
\text { cerad } \\
\text { fisk }\end{array}$ & & & \\
\hline 1 & $\begin{array}{l}\text { Syresättning och } \\
\text { utluftning av } \mathrm{CO}_{2}\end{array}$ & $\begin{array}{l}\text { Sättfiskodling för } \\
\text { laxfisk }(0,5-100 \\
\text { g), sötvatten. }\end{array}$ & 53,0 & 9,0 & 53000 & I.T. & 7 \\
\hline 2 & $\begin{array}{l}\text { Recirkulation med } \\
\text { partikelfilter, biofilter } \\
\text { och syresättning }\end{array}$ & $\begin{array}{l}\text { Sättfiskodling för } \\
\text { laxfisk }(0,5-100 \\
\text { g), sötvatten. }\end{array}$ & 40,0 & 4,0 & 6368 & 20,0 & 2 \\
\hline 3 & $\begin{array}{l}\text { Recirkulation med } \\
\text { partikelfilter, biofilter, } \\
\text { denitrifikationsfilter och } \\
\text { syresättning }\end{array}$ & $\begin{array}{l}\text { Matfiskodling } \\
\text { laxfisk }(10-500 \mathrm{~g}) \text {, } \\
\text { sötvatten. }\end{array}$ & 18,0 & 8,5 & 123 & 5,4 & 1 \\
\hline 4 & $\begin{array}{l}\text { Sedimenteringsan- } \\
\text { läggning vid avlopp }\end{array}$ & $\begin{array}{l}\text { Matfiskodling } \\
\text { laxfisk (10-500 g), } \\
\text { sötvatten. }\end{array}$ & 15,0 & 1,0 & 120 & I.T. & 5 \\
\hline 5 & $\begin{array}{l}\text { Recirkulation med } \\
\text { finfiltrering av partiklar, } \\
\text { biofilter, luftning och } \\
\text { transport med tryckluft }\end{array}$ & $\begin{array}{l}\text { Matfiskodling } \\
\text { laxfisk (10-500 g), } \\
\text { sötvatten. }\end{array}$ & 2,8 & 0,1 & 56 & 1,5 & 6 \\
\hline 6 & $\begin{array}{l}\text { Recirkulation med } \\
\text { partikelfilter, biofilter, } \\
\text { denitrifikationsfilter, } \\
\text { fosforfälla och syre- } \\
\text { sättning }\end{array}$ & $\begin{array}{l}\text { Matfiskodling för } \\
\text { plattfisk (piggvar, } \\
10-500 \mathrm{~g} \text { ), havs- } \\
\text { vatten. }\end{array}$ & I.T. & I.T. & 840 & 11,4 & 3 \\
\hline
\end{tabular}

Taulukko 1. Typen ja fosforin päästöt ja veden ja sähkön kulutus maalla sijaitsevissa kalanviljelylaitoksissa tarkasteltuna valituissaviitelaitoksissa. Näitä menetelmiä käytettäessä täytyy tarkentaa että päästötasot vaihtelevat kalalajin, veden lähteen laadun,ruokinta-annosten jne. mukaan. Annetut arvot ovat siksi vain ohjeellisia. E.K.= tietoa ei ole käytettävissä.

\section{Rehu- ja ulostepäästöt}

Lohikalojen istukaslaitoksissa viemärin suulla olevillapartikkelienkerääjillä, joissa on lietteenkerääjä voidaansaavuttaa päästötaso $40 \mathrm{~kg}$ typpeä/tonnia ja 4 kgfosforia/tonnia tuotettua kalaa. Menetelmän nro 3käyttäminen vähentää typpipäästöjä tasolta 45 tasolle18 kg/tonnia tuotettua kalaa (Taulukko 1). Lisäksifosforipäästöjä voidaan vähentää käyttämällämenetelmää nro 6, (Taulukko 1), mutta arvojasaavutettavista tasoista ei valitettavasti olekäytettävissä. Menetelmässä nro 5, (Taulukko 1)saavutetaan typen päästöarvojen pieneneminen tasolta52 tasolle 2,8kg/tonnia tuotettua kalaa ja fosforintasolta 9 tasolle $0,1 \mathrm{~kg} /$ tonnia tuotettua kalaa. 
Vertailun vuoksi todetaan, että nykyiset keskimääräisetpäästöt maalla sijaitsevista kalanviljelylaitoksista

Pohjoismaissa ovat tasolla $55 \mathrm{~kg}$ typpeä ja 8 kgfosforia/tonnia tuotettua kalaa.Käytettäessä menetelmiä, jotka kuvataan Taulukossa 1,täytyy tarkentaa, että päästötasot vaihtelevat kalalajin, veden lähteen laadun, ruokinta-annoksen jne. mukaan. Annetut arvot ovat siksi vain ohjeellisia.

\section{Sähkön ja veden kulutus}

Lohikalojen istukaslaitoksessa, missä käytetäänmenetelmää 1, voidaan veden kulutusta vähentää100:sta 53:een $\mathrm{m} 3 / \mathrm{kg}$ tuotettua smolttia (Taulukko 1).Jos käytetään menetelmää 2, voidaan veden kulutustavähentää tasolle 6,3 m3/kg tuotettua smolttia(Menetelmä nro 2, Taulukko 1). Sähkönkulutuskuitenkin lisääntyy sisäisen pumppauksen ja korkeanhapen liukenemisasteenyhteydessä. Tuotettaessa $10-500$ g lohikaloja voidaan saavuttaa veden kulutus $0,06 \mathrm{~m} 3 / \mathrm{kg}$ tuotettua kalaa, ja sähkön kulutus 1,5 kWh/kgtuotettua kalaa (Menetelmä nro 5, Taulukko 1). Maallasijaitsevissa merikalojen jatkokasvatuslaitoksissavoidaan saavuttaa vedenkulutustaso $0,8 \mathrm{~m} 3 / \mathrm{kg}$ tuotettuakalaa (Menetelmä nro 6 , Taulukko 1). Sähkönkulutuson silloin noin $11 \mathrm{kWh} / \mathrm{kg}$ tuotettua kalaa.

\section{Merellä sijaitsevien laitostenympäristövaikutukset}

Pohjoismaissa tuotettujen 7-10 lajin tuotantomäärä oliyhteensä 529.000 tonnia jakaantuen 1162 laitokselle(vuonna 2000). Suurin osa tuotannosta oli norjalaistalohta ja kirjolohta.

Merellä sijaitseviin laitoksiin istutetaan poikasia jaistukkaita, jotka ruokitaan teuraskokoon. Tämänvaiheen aikana suoritettavia prosesseja ovat ruokinta,kuolleiden kalojen poiminta, verkkokassienvaihtaminen, verkkokassien pesu, käsittely loisiavastaan, käsittely sairauksia vastaan ja kalojenkerääminen teuraaksi.

Merellä sijaitsevien kalanviljelylaitostenympäristövaikutus on peräisin rehunkulutuksesta,rehun ja ulosteiden päästöistä, lääkkeiden käytöstä,myrkyllisten ja mahdollisesti myrkyllisten kemikaalienkäytöstä, kuolleesta kalasta ja karkaamisesta, jätteistä,hajusta ja melusta.

\section{Rehunkulutus}

Rehunkulutus eri maissa on suoraan riippuvainenvuosittaisesta tuotantomäärästä. Vuonna 2001rehunkulutus oli Norjassa 659.311 tonnia, Färsaarilla81.000 tonnia ja Ahvenanmaalla 6.300 tonnia. 


\section{Lääkkeiden ja kemikaalien kulutus}

Lääkkeiden määritelmässä on otettu mukaan vainantibiootit.

Antibiootteja käytetään vainbakteerisairauksia saaneiden kalojen akuuttiinkäsittelyyn. Pohjoismaissa antibioottien kulutusvaihtelee välillä 0,005 ja $102 \mathrm{~g} /$ tonnia tuotettua kalaa,ja on alhaisin Ahvenanmaalla ja korkein Tanskassa.

Kemikaalit, joita käytetään ovat nukutusaineet, sienientorjunta-aineet, loisten torjunta-aineet sisältäenlohiloisen torjunta-aineet, kupari, desinfektioaineet japuhdistuskemikaalit. Vuonna 2001 kulutettiin 201tonnia kuparia Norjassa ja 31 tonnia Färsaarilla.Erilaisia lohiloisen torjuntaaineita kulutettiin 119 kgNorjassa ja 13,4 kg Färsaarilla.

\section{Rehu- ja ulostepäästöt}

Orgaaniset päästöt käsittävät rehun, ulosteet, typen jafosforin. Pohjalle sedimentoituvien partikkeleidenpäästöt riippuvat kalanviljely-yksikön alla olevastasyvyydestä ja virtausolosuhteista.

Fosforipäästöjen määrä riippuu ensisijaisesti hukkaanmenneen rehun ja ulosteiden määrästä. Typpipäästöjenmäärä riippuu hukkaan menneen rehun ja ulosteidenmäärän lisäksi myös rehun sisältämästä proteiinista.Suurin osa typestä joutuu ympäristöön liuenneessamuodossa, kun taas suurin osa fosforista kulkeutuuhukkaan menneen rehun ja ulosteiden mukana.

Tanskassa on alhaisin keskimääräinen päästötaso 45 kgtyppeä ja 5 kg fosforia per tonnia tuotettua kalaa.Ruotsissa ja Suomessa päästötaso on korkein, 59 kg Nja 7-8 kg fosforia per tonnia tuotettua kalaa. Joillakinsuomalaisilla laitoksilla päästötaso on alhainen, 36 kgtyppeä ja 4,3 kg fosforia/tonnia tuotettua kalaa.

\section{Karkaaminen}

Kalojen karkaaminen laitoksilta on suuri ongelma.Norjalaisilta kalanviljelylaitoksilta karkasi vuonna2000 noin 351.000 lohta ja kirjolohta, kun taasfärsaarelaisilta laitoksilta karkasi noin 1.000.000 lohtavuonna 2002.

\section{Jäte, haju ja melu}

Jäteproblematiikka on sama kuin maalla sijaitsevillalaitoksilla.

Verkkokassilaitoksen haju syntyy rehusta, kuolleestakalasta, kuivamassa olevien kasvatuskassien pinnallekiinnittyneistä kuolleista organismeista japuutteellisesta puhdistamisesta. Merellä sijaitsevienlaitosten mahdollinen melu rajoittuu henkilökuntaa jakalaa ja rehua kuljettavien veneiden moottorien ääneen.Ruokintalaitteista voi syntyä jonkin verran ääntä. Nämäeivät ole jatkuvia ääniä, vaan syntyvät satunnaisestipäivän 
aikana ja eri vuodenaikoina Sähkögeneraattoritvoivat myös aiheuttaa melua, mutta uudemmatgeneraattorit ovat hyvin äänieristettyjä eivätkä aiheutaoleellista meluongelmaa. Joillakin laitoksilla on paikanpäällä kasvatuskassien pesukone, joka voi aiheuttaajonkin verran melua, mutta ei yli 40-50 dB(A).

\section{Menetelmät, joiden voidaan katsoaolevan BAT merellä tapahtuvassakalankasvatuksessa.}

Menetelmät, joiden voidaan katsoaolevan BAT merellä tapahtuvassakalankasvatuksessa.

1. Lohen ja kirjolohen ruokakalalaitos, jossa ontunnistinjärjestelmä kalanruokailukäyttäytymisen ja rehunhukkamäärien muutosten havaitsemiseksi.

2. Lohen ja kirjolohen ruokakalalaitos, jossa onhukkarehun ja kuolleiden kalojenkeräilyjärjestelmä.

3. Lohen ja kirjolohen ruokakalalaitos, jossakäytetään huulikaloja lohiloisten poistoon.

4. Lohen ja kirjolohen ruokakalalaitos, jossa onautomaattinen kasvatuskassienvaihtojärjestelmä.

\section{Menetelmiä, jotka vähentävät orgaanisenaineen päästöjä.}

Merellä sijaitsevissa laitoksissa ympäristöpäästöjensuurin pieneneminen saavutetaan vähentämällä rehunhukkaa, koska hukkarehulla on suurempivajoamisnopeus kuin ulosteilla, ja siksi sesedimentoituu keskitetymmin laitoksen alle. Seuraavatmenetelmät voivat auttaa vähentämään orgaanisenaineen päästöjä ja kuormitusta resipientissä:

- Sellaisten ruokintalaitteiden käyttö, joihin onohjelmoitu kasvumallit, jotka ottavat huomioonlämpötilan, päivän pituuden ja joissa onkasvatuskassin pohjan päälle tai alle asennetuttunnistimet, jotka rekisteröivät syömättä jääneenrehun ja kalan aktiivisuuden (KuvaKuva4).

- Sellaisen keräilyjärjestelmän käyttö, joka keräähukkarehun ja kuolleet kalat, jotka muutenkuormittaisivat pohjaa/ympäristöä laitoksen alla(Kuva 5). Jatkuva kuolleiden kalojen keräilyvarmistamaan muun biomassan terveydentila. 

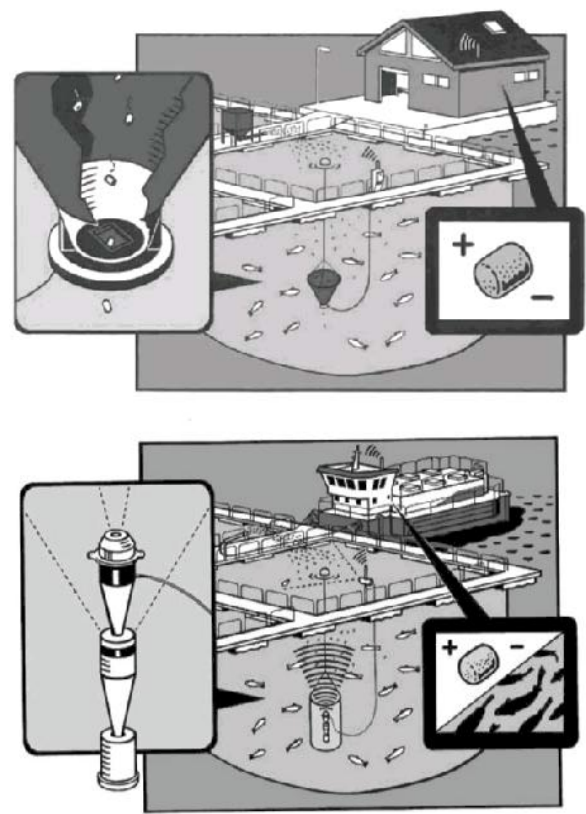

Kuva 4. Periaatepiirros merellä sijaitsevastakalankasvatuslaitoksesta, jossa on hukkarehun rekisteröiväinfrapunavalon (yllä) ja doppler tunnistimen (alla) sisältäväruokintajärjestelmä.

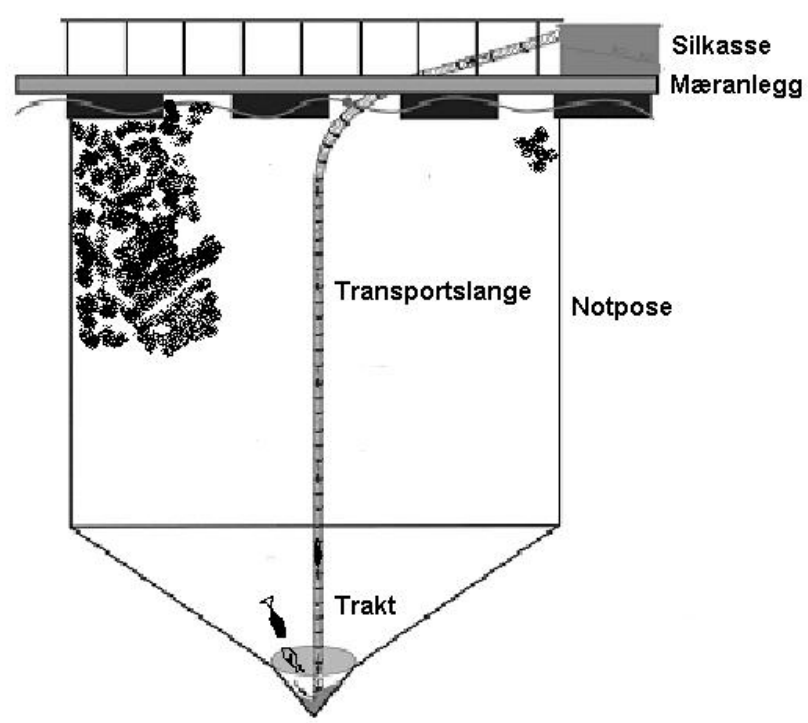

Kuva 5 Periaatepiirros hukkarehun, ulosteiden ja kuolleidenkalojen keräilyjärjestelmästä. 
Menetelmiä, jotka varmistavat olemassa olevanbiomassan hyvän terveydentilan.

Seuraavat menetelmät voivat auttaa varmistamaankalanviljelylaitoksessa olevien kalojen hyvänterveydentilan

- Kalatiheyden sovittaminen kunkin paikanvirtausnopeuden ja lämpötilan mukaan.

- Ympäristöparametrien konsentraatioidensäännöllinen seuranta. Tällaisia parametreja ovatammoniakki ja happi loppukesällä ja syksyllä,erityisesti virtapaikoissa, joissa veden vaihtuvuuson pieni.

- Huulikalan (Kuva 6) käyttäminen lohiloisenlaiduntajana alueilla, joilla on suurempia villinhuulikalan esiintymiä.

- Synkronoidut, alueelliset lohiloisen torjunnat,esimerkiksi keväällä poistamaan mahdollisimmanpaljon sukukypsiä loisia ennen kuin lämpötila jasiten loisen lisääntymiskyky nousee.

- Vähennetyn valaistuksen käyttö kasseissa pinnaltatulevan valon sijaan edistämään lohien jakautumistasyvemmälle kasseissa vuorokauden ympäri, mikäjohtaa vähentyneisiin lohiloistartuntoihin.

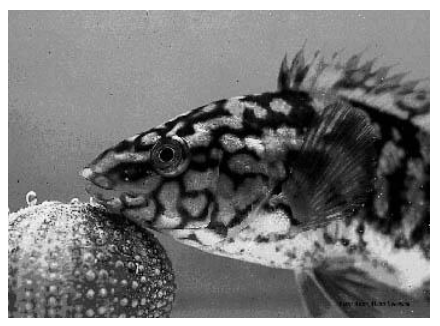

Kuva 6. Viherhuulikala.

Menetelmiä, jotka vähentävät kemikaalienpäästöjä

Merellä sijaitsevissa laitoksissa käytetyistäkemikaaleista on eniten käytetty kuparikyllästäminen.Seuraavat menetelmät voivat vähentää/ eliminoidakuparikyllästämisen käytön;

- Kasvatuskassien kuivattaminen kassin pinnanleväkasvuston poistamiseksi käyttämällä kahdenkasvatuskassin settiä, missä toinen kassi vedetäänylös ja kuivataan, sillä aikaa kun toinen on meressä.

- Kasvatuskassin molemmin puolin asennettujensähkökäyttöisten rumpujen käyttö (Kuva 7)isommilla laitoksilla yksinkertaistamaankasvatuskassin vaihtoa ja stimuloimaan useammintapahtuviin suurempien kasvatuskassien vaihtoihin.

- Meressä olevan kasvatuskassin ylimpien 2-3 metrinhuuhtelu painepesurilla, erikoisvalmisteisellalaitteella, joka liitetään korkealla paineella tulevaanveteen (Kuva 8). 


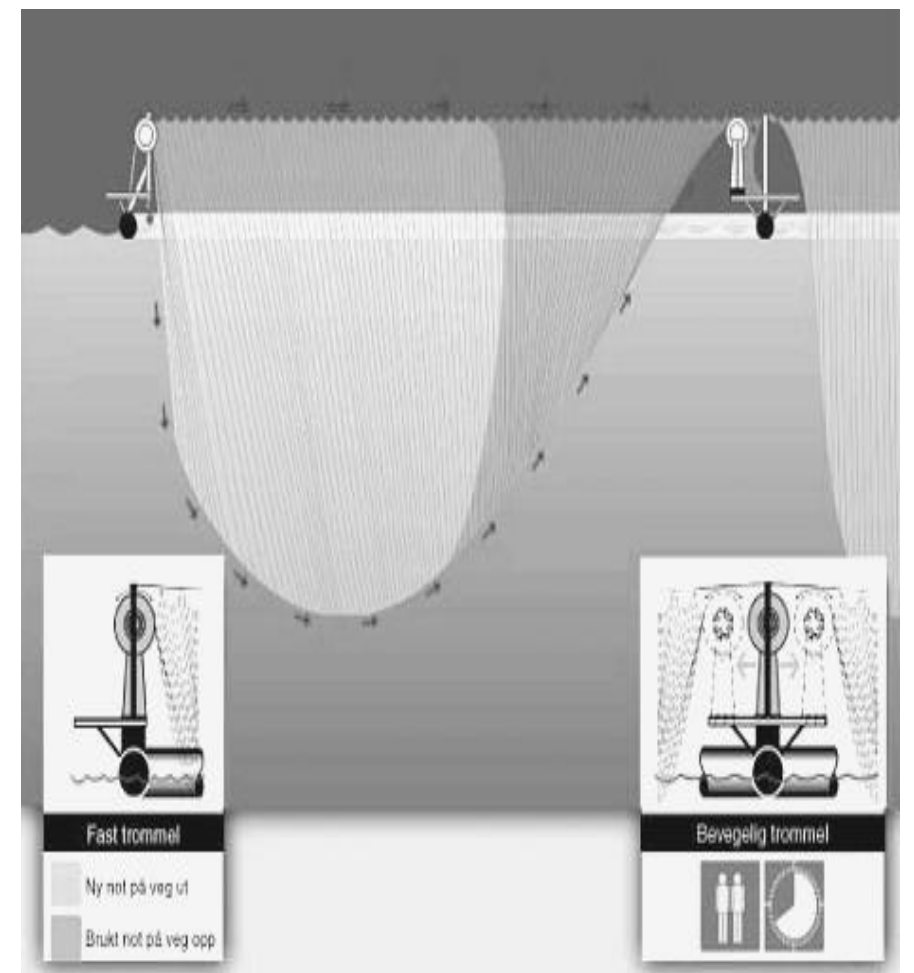

Kuva 7 Periaatepiirros automaattisesta kasvatuskassinvaihtojärjestelmästä merellä sijaitsevassa ruokakalalaitoksessa.Kuvassa sekä kiinteä rumpu että liikuteltava rumpu.

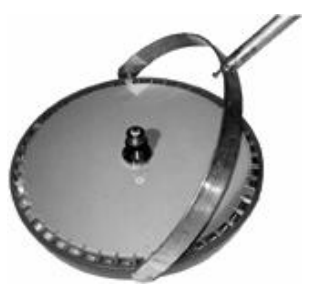

Kuva 8. Kasvatuskassien seinien pesukone.

\section{Menetelmiä, jotka vähentävät kalojenkarkaamista ja karkaamisen haitallisiavaikutuksia}

Erityisen laitostekniikan valintaan vaikuttaa se, mitenvoimakkaasti sijainti on alttiina esim.tuulenvoimakkuus ja aallonkorkeus. Norjassa on otettukäyttöön hyväksyntäjärjestelmä kelluville laitoksille jakansallinen standardi kelluville kalanviljelylaitoksille(NS9415 - Kelluvat kalanviljelylaitokset. Suunnittelun,mitoituksen, toteutuksen, asennuksen ja toiminnanvaatimukset). Standardi tuli voimaan 1.4.2004.Standardin tarkoituksena on vähentääkalanviljelylaitoksen teknisestä pettämisestä taivirheellisestä käytöstä johtuvaa karkaamisriskiä.Kaikkien laitteiden, joita käytetään standardinvoimaantulon jälkeen, on oltava tuotesertifioituja, kuntaas olemassaolevien kalanviljelylaitosten täytyy saadakelpoisuustodistus ennen vuotta 2006. Tämädokumentoi laitoksen vastuullisen teknisen ta- 
son.Esimerkkejä erilaisista laitoksista, joita käytetään säillealttiilla alueilla Kuva 9 ja Kuva 10).

- Kasvatuskassin tarkistaminen ja yksityiskohtaistenmenettelytapojen kehittäminen käsittelyyn,kasvatuskassin tarkastukseen ennen ja jälkeenmereen sijoittamisen, sen laitokseen asentamiseenja tuotantorutiineihin (kuten esim. veneen käydessälaitoksella).

- Törmäysonnettomuuksien estämisen varmistaminenlaitoksella tapahtuvan liikenteen yhteydessäriittävällä laitoksen valaistuksella, vilkkuvienlyhtyjen lisäksi, erityisesti silloin kun näkyvyys onhuono.

- Kiinnitysköysien ja kasvatuskassien säännöllisettarkastukset ja huolto kasvatuskassien reikien sekäkiinnitysköysien ja laitoksen ankkurointienheikkouksien paljastamiseksi.

- Kasvatuskassien vaihtaminen usein, jottakasvatuskassien tilaa voidaan hyvin kontrolloida.

- Säännöllinen tarkkailukalastus verkoilla kalojenkarkaamisen havaitsemiseksi nopeasti.

- Rutiinien kehittäminen veneiden laitoksellakäyntien, kuten istukkaiden tuonnin, lohiloisentorjunnan, kasvatuskassien vaihdon, rehunkuljetuksen ja kalojen keräämisen (sadonkorjuun)yhteyteen.

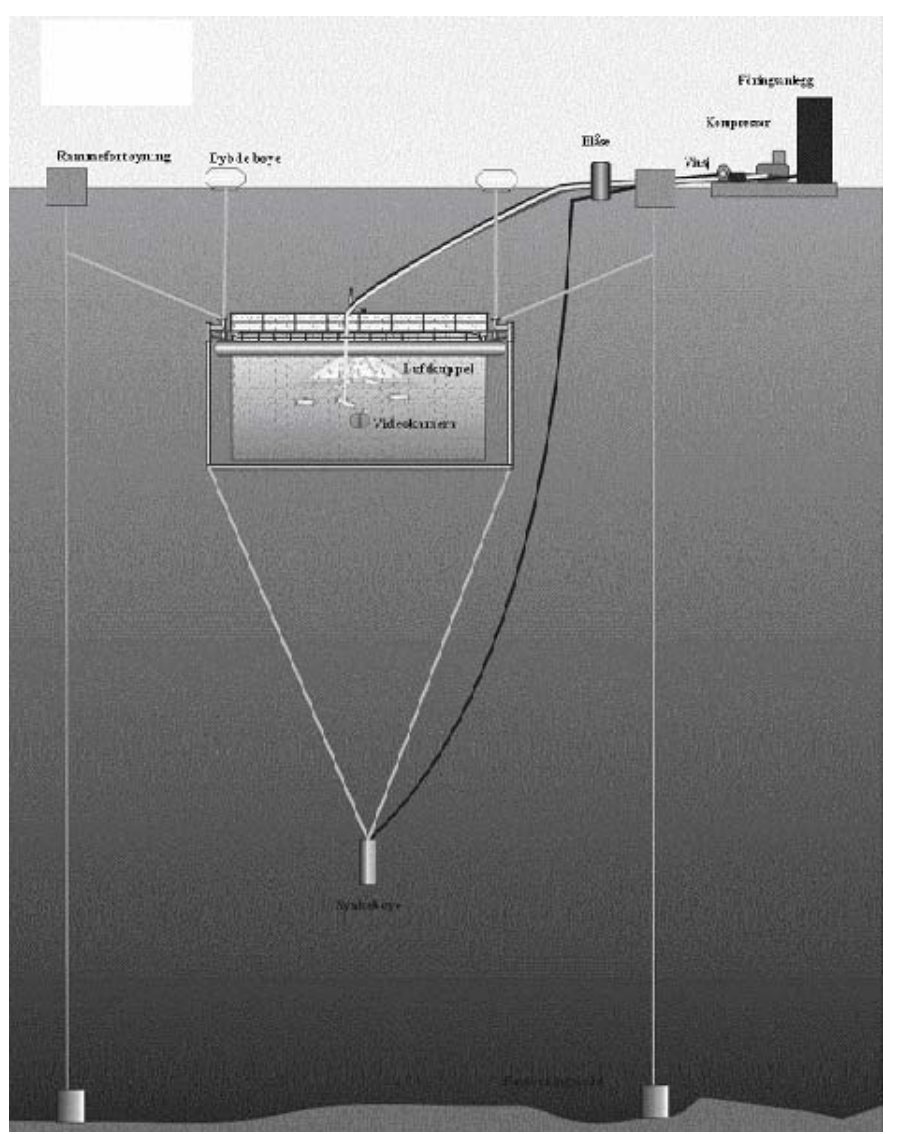

Kuva 10. Periaatepiirros lohi- ja turskakalojen tuotantoontarkoitetusta alaslaskettavasta verkkokassista. 


\section{Menetelmiä, jotka vähentävät melua}

Merellä sijaitsevista verkkokassilaitoksista meluasyntyy sähköaggregaateista, kuolleen kalan myllyistä jamahdollisesti pesukoneista, mikäli kasvatuskassitpestään laitoksilla itse. Seuraavat toimenpiteetvähentävät merellä sijaitsevilla kalanviljelylaitoksillasyntyvää melua;

- Hiljaisten tai eristettyjen sähköaggregaattien käyttö.

- Kasvatuskassien kuivattaminen pesukoneen käytönsijaan laitoksella, erityisesti jos laitos sijaitseeasutuksen lähellä.

- Ruokintapisteen sijoittaminen veden alle melunvähentämiseksi ruokittaessa kuivarehulla, mikäliruokintajärjestelmä sen sallii.

\section{Estetiikka}

Otettaessa huomioon muut käyttäjäintressit niilläalueilla, joilla kalanviljelylaitokset ovat, pitäisisuorittaa seuraavia toimenpiteitä laitoksensilmiinpistävyyden vähentämiseksi;

- Köysien kiinnityspoijujen väri ei saa haitataympäristöä.

- Kiinnitysköysien pitää olla järjettetty niin, että neon helppo huomata.

- Laitoksen valaistuksen on oltava sammutettunaöisin biologisia prosesseja kuten sukukypsyydensaavuttamista ohjaavaa valaistusta ja merkkivalojalukuun ottamatta.

- Biologisia prosesseja ohjaavan valaistuksen pitääolla upotettuna merenpinnan alapuolelle.

\section{Menetelmiä laitoksen sijoittamiseksi jaympäristön tilan tarkkailemiseksi}

Optimaalisen paikan löytäminen kalanviljelylaitokselleon taloudellisesti tuottavan toiminnan avainedellytys.Laitoksen sijoittamisessa täytyy ottaa huomioonseuraavaa;

- On tehtävä asiantuntija-arvio paikan vuotuisistaympäristöolosuhteiden vaihteluista suhteessakasvatettavan lajin ympäristövaatimuksiin.

- 1-5 km säteellä ei saa olla ollenkaankalanviljelytoimintaa tai kalanviljelytoiminta onvähentynyt.

- Laitosta ei pidä sijoittaa kynnysvuonoihin eikäheikkovirtaisiin kynnysaltaisiin.

- Virtausnopeutta $5 \mathrm{~cm}$ sekunnissa tai enemmänsuositellaan varmistamaan riittävä kalojen hapensaanti ja jäteaineiden leviäminen. Alhaisillakalatiheyksillä veden vaihtuvuuden vaatimustavoidaan jonkin verran pienentää. 
Menetelmiä alueen pohjan olosuhteista huolehtimiseksija sedimentin tilan tarkkailemiseksi

Sukupolvituotanto ja jokaisen kalankasvatuspaikankesannointi tarkoittaa, että jokaisella meressäsijaitsevalla kalanviljelylaitoksella täytyy olla käytössä3-4 paikkaa, joita käytetään vuorotellen. Tässäkonseptissa eri sukupolvet pidetään erillään eripaikoissa ja yksi paikka on aina kesannolla.

Sukupolvituotanto vähentää tautitartuntaa mereenistutettavien sukupolvien välillä, ja yhden paikankesannointi tuotantosyklin läpi mahdollistaa laitoksenalla olevan pohjaeläimistön ennalleen palautumisen, janäin vältetään myös hapettomien olosuhteidenkehittyminen. Hapettomissa olosuhteissa muodostuuusein kaasuja kuten metaania ja rikkivetyä, jotka taasovat suoraan myrkyllisiä kaloille.

Kun pohjaeläinkoostumus on kehittynythyväksyttävälle tasolle, kalat voidaan istuttaakyseiselle paikalle. Pohjan olosuhteiden hoitamiseksitietyllä paikalla suositellaan:

- Sedimentin tilan valvontaa MOM -menetelmällä(Matfiskanlegg overvåkning - modellering,Ruokakalalaitos - valvonta mallintaminen) jokaon järjestelmä, jota voidaan käyttää säätelemäänmereisten kalanviljelylaitosten ympäristövaikutustaalueen kantokyvyn mukaan (NS 9410),

- Sedimentin tilan arviointia kuparin ja sinkinpitoisuuksien raja-arvojen avulla annettujenlaskentalinjojen mukaan.

- Sukupolvituotannon ja alueen kesannoinnin käyttöävähentämään tautitartuntaa sukupolvien välillä javälttämään hapettomia olosuhteita laitoksen alla.

- Kesannointijakson pituuden arviointiapohjaeläinkoostumuksen ja sedimenttien orgaanisenhiilen kokonaismäärän (TOC) avulla, koska TOC -arvon ja pohjaeläinkoostumuksen välillä onläheinen yhteys.

\section{BAT tasot}

Tässä kappalee ssa esitetyt tasot vaihtelevat sijainnistariippuvien spesifisten olosuhteiden mukaan ja niidenon siksi katsottava olevan vain ohjeellisia.Investointikustannukset vaihtelevat myös paljonPohjoismaiden välillä ja jälleen täytyy annettuja arvojavain pitää ohjeellisina

\section{Rehu- ja ulostepäästöt}

Vaikka yksittäiset kalanviljelyviranomaisetPohjoismaissa ovatkin aloittaneet käytännön, jossakuhunkin lupaan sisältyy rajoitettu rehumäärä,rehunkulutus vähenee pääasiassa käyttämällämenetelmiä, jotka tunnistavat hukkarehun ja valvovatkalojen aktiivisuutta ja vertikaalista jakautumista.Sellaiset järjestelmät johtavat siihen, että voidaansaavuttaa rehukerroin alle 1,00. Näin voidaan typen jafosforin päästöt saada tasolle 45 
kg N/tonnia ja 5 kgP/tonnia tuotettua kalaa. Menetelmä, joka keräähukkarehun kasvatuskassin pohjalta ja kuljettaa senpinnalle yhdessä kuolleiden kalojen kanssa, vähentääpäästöjä vastaavalle tasolle kuin käytettäessäruokintalaitteita, jotka tunnistavat hukkarehun.Edelleen viimeksi mainittu menetelmä vähentääpaikallisesti orgaanista kuormitusta, koska sekähukkarehu että ulosteet kerätään talteen.

\section{Lääkkeiden ja kemikaalien kulutus}

Lääkkeiden, pääasiassa antibioottien, kulutus on 102g/tonnia tuotettua kalaa Tanskassa varrattuna 0,005-1g/tonnia tuotettua kalaa muissa Pohjoismaissa. Syysuureen antibioottien kulutukseen Tanskassa onfurunkuloosin ja ERM-taudinesiintymien korkeamäärä. Tanskassa rokotetaan vain 20-25 \% kaikistamereen istutettavista kaloista, kun muissaPohjoismaissa luku on lähes $100 \%$. Pohjoismaissatavallisia kalapatogeenisiä sairauksia vastaanyksilöllisesti rokotettujen istukkaiden ostaminen voivähentää antibioottien kulutusta yli $99 \%$

Lohiloisen torjunta-aineiden käyttö lohen ja kirjolohenviljelyssä voidaan sulkea pois käyttämällä huulikaloja.Tämä on menetelmä, jota käytetään vain Norjassa.Tämä johtuu siitä, että suurempia määriä niitä erihuulikalalajeja, joita käytetään loistentorjunnassa,esiintyy vain Norjassa.

Kasvatuskassien kuivattaminen vähentääkuparipitoisilla aineilla kyllästämisen tarvetta, ja voisiten sulkea pois kuparin käytön. Toinen kassi riippuukuivamassa, kun toinen on käytössä. Suurilleteräslaitoksille on olemassa automaattisia menetelmiä,jotka helpottavat kasvatuskassin vaihtotyötä.Automaattista menetelmää ei kuitenkaan voida käyttääsuurien pyöreiden muovirenkaiden päällä. Sellaisilleverkkokasseille on olemassa painepesureita, jotkapoistavat leväkasvun 2-3 ylimmän metrin osalta kunkasvatuskassi on meressä. Menetelmää voidaan käyttääkasvatuskassin reunalta. Kasvatuskassin pesu kolmeametriä syvemmällä vaatii ammattisukeltajien apua.

\section{Karkaaminen}

Karkaamisen vähentämistä edistäviä menetelmiä voivatolla laitoksen rakenteiden sopeuttaminen sen mukaan,miten altis sijainti on sään vaihteluille sekäupotettavien kasvatuskassien käyttäminen erityisenalttiilla alueilla. Muut menetelmät, kutenkasvatuskassin rutiinitarkastus, varmistus liikenteenvaralta, laitoksen huolto, usein tapahtuvakasvatuskassin vaihto, tarkkailukalastus verkoilla jarutiinit veneiden laitoksella käyntien yhteydessä voivatauttaa vähentämään karkaamista jopa 100 \%. 


\section{Kehitys tulevaisuudessa}

Tämänhetkinen kalanviljelyn ympäristövaikutuksiavähentävien menetelmien tutkimus ja kehitys käsittäämm.:

- kohtuullisten menetelmien kehittäminen vedenkierrätykseen, ulosteiden keräämiseen, lietteenkäsittelyyn, lietteen jälkikäsittelyyn,vedenkulutuksen sekä lääkkeiden ja kirjolohenkasvatuksen apuaineiden käytön vähentämiseen(Tanska),

- suljetun kasvatuskassin ja siihen kytketynpuhdistusyksikön kehittäminen, joka tähänmennessä on vähentänyt fosforipäästöjä 90 \% (Suomi),

- yritykset käyttää entsyymikäsiteltyä kuollutta kalaaväriaineen ja lannoitteen valmistukseen (Suomi),

- yritykset käyttää entsyymikäsiteltyä kuollutta kalaaväriaineen ja lannoitteen valmistukseen (Suomi),

- vedenkäsittelylaitosten kehittäminen merellisienkalalajien poikasten tuotannossa (Norja),

- kalanviljelylaitosten optimaalinen sijoittaminen(Norja ja Suomi),

- lohen ja kirjolohen kasvatuksensoveltuvuusanalyysit suhteessa vuorovesivirtauksiinja aaltoihin (Färsaaret).

\section{Kirjallisuus}

Parhaat käytettävissä olevat menetelmät (BAT) kalanviljelyyn Pohjoismaissa, Pohjoismaiden

Ministerineuvosto, TemaNord 2005:528. 